\title{
Influence of the UAN Fertilizer Application on Quantitative and Qualitative Changes in Semi-Natural Grassland in Western Carpathians
}

\author{
Mirela Ranta ${ }^{1}$, Ioan $\operatorname{Rotar}^{1}$, Roxana Vidican ${ }^{1}$, Anamaria Mălinaș ${ }^{1}$, Ovidiu Ranta ${ }^{2, *}$ and Nicoleta Lefter ${ }^{3} \mathbb{D}$ \\ 1 Department of Plant Culture, Faculty of Agriculture, University of Agricultural Sciences and Veterinary, \\ Medicine, 400372 Cluj-Napoca, Romania; mirela.ranta@usamvcluj.ro (M.R.); ioan.rotar@usamvcluj.ro (I.R.); \\ roxana.vidican@usamvcluj.ro (R.V.); anamaria.malinas@usamvcluj.ro (A.M.) \\ 2 Department of Technical Sciences and Soil Sciences, Faculty of Agriculture, University of Agricultural \\ Sciences and Veterinary Medicine, 400372 Cluj-Napoca, Romania \\ 3 National Research Development Institute for Animal Biology and Nutrition Balotesti, 1 Calea Bucuresti, \\ District Ilfov, 077015 Balotesti, Romania; ciuca_nicoleta@yahoo.com \\ * Correspondence: ovidiu.ranta@usamvcluj.ro
}

Citation: Ranta, M.; Rotar, I.; Vidican, R.; Mălinas, A.; Ranta, O.; Lefter, N. Influence of the UAN Fertilizer Application on Quantitative and Qualitative Changes in Semi-Natural Grassland in Western Carpathians. Agronomy 2021, 11, 267. https:// doi.org/10.3390/agronomy11020267

Academic Editors: Gianni Bellocchi and Catherine Picon-Cochard

Received: 21 December 2020

Accepted: 28 January 2021

Published: 31 January 2021

Publisher's Note: MDPI stays neutral with regard to jurisdictional claims in published maps and institutional affiliations.

Copyright: (c) 2021 by the authors. Licensee MDPI, Basel, Switzerland. This article is an open access article distributed under the terms and conditions of the Creative Commons Attribution (CC BY) license (https:// creativecommons.org/licenses/by/ $4.0 /)$

\begin{abstract}
Semi-natural grasslands are particularly important in mountainous areas of Romania, being the only source of forage for many farmers. The aim of this study was to investigate the changes in forage quantity and quality as a result of Urea Ammonium nitrate (UAN) liquid fertilization. The experiment was carried out in the eastern part of Apuseni Mountains, Romania on a Festuca rubra L.Agrostis capillaris L. grassland located at $1240 \mathrm{~m}$ altitude. Studies were made over three years of experimental trial (2014-2016) and covered four experimental plots in three replicates, as follows: V1-control plot, unfertilized; V2-plot fertilized with $50 \mathrm{~kg} \mathrm{UAN} \mathrm{ha}^{-1}$ year $^{-1}$; V3-plot fertilized with $75 \mathrm{~kg}$ UAN ha ${ }^{-1}$ year $^{-1}$, and V4-plot fertilized with $100 \mathrm{~kg} \mathrm{UAN} \mathrm{ha}^{-1}$ year $^{-1}$. The experimental plots were harvested once per year and the botanical composition, dry matter yield and forage quality were assessed. Our results showed important changes in forage quantity, quality and diversity as a result of UAN fertilization. Starting from the second experimental year the dominance/co-dominance ratio changed favoring the species from Poaceae family. Dry matter increased as a result of UAN fertilization but forage quality was negatively affected by the higher percentage of participation of species from other botanical families which have higher crude fiber content and lower crude protein. Based on our results we recommend moderate fertilization with UAN up to $50 \mathrm{~kg} \mathrm{UAN} \mathrm{ha}^{-1} \mathrm{year}^{-1}$ for semi-natural grasslands located in soil-climatic conditions similar to those in our experiment.
\end{abstract}

Keywords: mineral fertilization; floristic composition; Festuca rubra L.; Agrostis capillaris L.; forage quality

\section{Introduction}

Grassland ecosystems cover from a third up to a half of the agricultural land in the countries in South-Eastern and Central Europe. They extend from the lowlands to the uplands and are a part of the agricultural landscape [1,2]. Grasslands are considered not only as a source of grazing and hay for herbivores, but they also play a multifunctional ecological and social-economic role, offering ideal conditions for a vast diversity of habitats and species [3]. The grassland area in Europe has been affected by significant changes in recent decades, including abandonment and conversion to arable land [4]. Most of the European countries have lost over $90 \%$ of their semi-natural grasslands because the productivity has been abandoned or intensified during the last century [5,6].

Romania has one of the largest grassland areas in Europe, still managed with traditional methods [7]. The pastoral area of Romania, covering of over 4.8 million ha, has been influenced, over the last decades, by natural and anthropogenic or human factors, which affect the normal functioning of the grassland ecosystem [8]. Among the most important 
natural factors affecting the primary productivity of grassland ecosystems the climatic (temperature and precipitation) and soil conditions play the most crucial roles. Previous studies have documented that changes in temperature and precipitation have a strong influence on temporal patterns in the biomass of grassland [9]. Nevertheless, grasslands are closely linked to the way they are being used and they can be very easily shifted from one extreme to the other, known as abandon-intensive exploitation [10]. Despite the fact that across much of Europe, the semi-natural grasslands, during the last 50 years, have become increasingly rare, the low intensification levels and the small-scale agriculture (the low-intensity agricultural habitats are one of the most valuable biodiversity sources), have led to the preservation of certain important areas in Romania. The regularly grazed or cut vegetation may contain some of the highest plant densities in Europe, or even in the world and thus the highest importance should be given to adopting the proper management for these ecosystems [11,12].

Most of experimental studies pointed out that the net primary production and plant diversity varies with the different locations and grassland ecosystems due to differences of resource availability [13]. The productive potential and quality of permanent grasslands could be increased by different fertilization regimes and types of mineral/organic fertilizers [14]. Several research works pointed out that biomass yield is positively influenced by fertilizer application. Among the most important nutrients, nitrogen $(\mathrm{N})$ holds an outstanding role in agricultural production [15]. Liquid chemical fertilizers are also used for efficient grassland fertilization and not only for large crops [16], and among the most recommended ones is the Urea Ammonium nitrate (UAN). UAN provides prolonged nutrition of plants with nitrogen and because only one-half of the $\mathrm{N}$ is in the urea form, the loss potential is lower than with straight urea. However, volatile losses are greatly reduced if less than 0.25 inches of precipitation occurred within a day or two after the application of the urea [17]. Nitrogen losses in air and to groundwater by leaching are higher in intensively-managed grasslands than in arable crops [18]. Therefore, in order to improve the sustainability of grassland husbandry it is necessary to take into account the environmental risk through nitrogen losses associated with nitrogen management. Assessing the efficiency of nitrogen application is a valuable first step in establishing an optimum $\mathrm{N}$ fertilizer management plan $[15,19]$.

Considering the potential effect of nitrogen fertilization on grassland ecosystems, several research works recommended that we should be carefully in adopting the optimum fertilization treatments since this change in management not only increases plant density and biomass, but also reduces the structural and floristic diversity of the sward $[20,21]$. The floristic composition is established based on scientific criteria, depending on the climate conditions, the exploitation manner and the agro-technique used [22]. The experiments conducted so far, nationally and internationally, show that species richness is reduced along with the intensification of the grassland systems, which leads to the installation of the species with a higher forage value and a better productivity [23].

Taking into account these concerns we strongly believe that a deeper understanding of how fertilization practices may induce changes in grassland productivity and quality is essential for the biodiversity management and semi-natural grassland conservation [24]. In this frame, the aim of our study is to track the changes occurred in quantitative and qualitative indices of semi-natural grassland as a result of UAN fertilization. We aim to determine the optimum fertilization regime for semi-natural grassland located in condition similar to those experimented in this trial. In order to achieve the proposed objectives we followed the effect of different rates of UAN fertilizer on dry matter production (DM), species composition and forage quality among three experimental years.

\section{Materials and Methods}

\subsection{Study Site}

The investigation was carried out during three experimental years (2014-2016) at a mountain semi-natural grassland located in Baisoara commune, Transylvania, Apuseni 
Mountains, at an altitude of $1240 \mathrm{~m}$ above sea level (latitude of 46.56439 and longitude of 23.33726).

The daily weather data were collected by a fully automated weather station located close to the experimental field. In this research, we present the average monthly air temperature, the annual average temperature, and the long-time monthly average temperature (LTA; Table 1). The highest annual average temperature was recorded in the year 2014 $\left(7.1^{\circ} \mathrm{C}\right)$, followed by the year $2016\left(7.0^{\circ} \mathrm{C}\right)$ when the annual average temperature was pretty closed to that recorded in 2016 . The lowest annual average temperature recorded during the 3-year experimental trial was reached in $2015\left(6.6^{\circ} \mathrm{C}\right)$. Comparing the average monthly air temperature for the 3-year experimental trial with the LTA (2004-2016), we observed that the monthly and annual average temperature recorded in the years 2014 and 2016 are much higher than the LTA, while the values recorded in the year 2015 are closer to the LTA.

Table 1. Average monthly air temperature for the three experimental years and the long-time average temperature (LTA).

\begin{tabular}{|c|c|c|c|c|}
\hline \multirow[b]{2}{*}{ Months } & \multicolumn{4}{|c|}{ Experimental Years } \\
\hline & 2014 & 2015 & 2016 & $\begin{array}{c}\text { LTA * } \\
\text { 2004-2016 }\end{array}$ \\
\hline January & 1.1 & -1.9 & -4.7 & -3.5 \\
\hline February & 2.7 & -2.8 & 0.3 & -3.1 \\
\hline March & 3.1 & -0.1 & 0.5 & -0.4 \\
\hline April & 3.2 & 3.2 & 8.1 & 5.1 \\
\hline May & 9.1 & 10.2 & 8.5 & 10.0 \\
\hline June & 12.4 & 13.4 & 14.6 & 13.3 \\
\hline July & 15.6 & 17.4 & 16.8 & 15.7 \\
\hline August & 15.0 & 17.5 & 17.6 & 15.5 \\
\hline September & 11.4 & 12.9 & 13.1 & 11.7 \\
\hline October & 8.2 & 6.0 & 5.7 & 6.8 \\
\hline November & 4.5 & 4.5 & 4.1 & 3.1 \\
\hline December & -0.9 & -0.7 & -0.6 & -1.0 \\
\hline $\begin{array}{l}\text { Annual average } \\
\text { temperature }\end{array}$ & 7.1 & 6.6 & 7.0 & 6.1 \\
\hline
\end{tabular}

* LTA-long-time monthly and annual average temperature, between the years 2004-2016.

The data recorded for rainfalls are presented in this research as the monthly sum of rainfalls, annual sum and the long-time average rainfalls (LTA; Table 2). When analysing the weather data recorded during the 3-year experimental trial we observe that the annual sum of rainfalls occurred in the years 2015 and 2016 are much greater than the LTA. The highest amount of rainfalls peaked in the year $2016(1181.0 \mathrm{~mm})$, while the lowest annual sum of rainfalls was recorded in the year $2014(908.7 \mathrm{~mm})$. The rainiest months were May and August for 2014 and 2015 while the highest amount of rainfall in the year 2016 peaked in June, July and August.

Soil samples were randomly taken from the experimental field area at a depth of 0-25 cm, each year to estimate soil properties (Table 3). The dominating soil type is Lithic Regosols. The average soil properties for the 3-year experimental trial are presented in Table 3. The $\mathrm{pH}$ changed during the experimental years but still remained acidic. 
Table 2. Total rainfall and rainfall distribution ( $\mathrm{mm}$ ) for the three experimental years and the long-time total rainfall (LTA).

\begin{tabular}{|c|c|c|c|c|}
\hline \multirow[b]{2}{*}{ Months } & \multicolumn{4}{|c|}{ Experimental Years } \\
\hline & 2014 & 2015 & 2016 & $\begin{array}{c}\text { LTA * } \\
2004-2016\end{array}$ \\
\hline January & 29.9 & 59.9 & 60.3 & 49.4 \\
\hline February & 14.7 & 39.3 & 83.9 & 38.0 \\
\hline March & 59.9 & 50.5 & 65.1 & 64.6 \\
\hline April & 87.9 & 51.8 & 102.6 & 75.1 \\
\hline May & 172.3 & 129.8 & 83.5 & 112.9 \\
\hline June & 92.3 & 212 & 144.2 & 141.8 \\
\hline July & 95.6 & 40.8 & 168.5 & 115.1 \\
\hline August & 116.5 & 127.5 & 144.2 & 100.9 \\
\hline September & 49 & 194.8 & 133.7 & 74.8 \\
\hline October & 74.7 & 64.1 & 61.1 & 59.4 \\
\hline November & 34.1 & 91 & 97.2 & 52.0 \\
\hline December & 81.8 & 7.7 & 36.7 & 56.2 \\
\hline Annual sum & 908.7 & 1069.2 & 1181.0 & 940.1 \\
\hline
\end{tabular}

* LTA-long-time monthly and annual average rainfalls, between the years 2004-2016.

Table 3. Soil characteristics in the experimental site*.

\begin{tabular}{cc}
\hline Agrochemical Index & Value \\
\hline $\mathrm{pH}$ in $\mathrm{H}_{2} \mathrm{O}$ & 4.55 \\
Humus (\%) & 2.16 \\
Nitrogen index (IN; \%) & 0.12 \\
Mobile P (ppm) & 11.14 \\
Mobile K (ppm) & 72.50 \\
\hline
\end{tabular}

* The chemical analysis of the soil weas delivered by specialists from the Department of Pedology, University of Agricultural Sciences and Veterinary Medicine from Cluj-Napoca, Romania.

\subsection{Experimental Set Up}

The experiment was placed after the randomized block method, in three replications. The research covered three blocks (parcels) and 4 levels of UAN fertilization: V1control plot (unfertilized), V2-fertilized with $50 \mathrm{~kg} \mathrm{UAN} \mathrm{ha}^{-1}$ year $^{-1}$, V3-fertilized with $75 \mathrm{~kg} \mathrm{UAN} \mathrm{ha}^{-1}$ year $^{-1}$, V4-fertilized with $100 \mathrm{~kg} \mathrm{UAN} \mathrm{ha}^{-1}$ year $^{-1}$.

The fertilizer was applied annually, in early spring (early March), to avoid volatilization, in the form of liquid mineral fertilizer. UAN is a mixture of ammonium nitrate and urea, with the chemical formula: $\mathrm{NH}_{4} \mathrm{NO}_{3} \mathrm{NH}_{2}-\mathrm{CO}-\mathrm{NH}_{2}$. UAN is a liquid that ranges from colourless to yellow and has a total nitrogen content of $32 \%$ (the nitrogen in nitrate form is $15.5 \%$ ). The fertilizer equipment was adapted using a $1.5 \mathrm{~m}$ ramp and special FD-type nozzles for liquid fertilization.

At each harvest floristic composition, dry matter yield (DM), crude protein content $(\mathrm{CP})$, crude fat (\%), crude fibre (\%), ash content (\%), NDF (\%), and ADF (\%) were assessed. Data presented in this paper are the result of 1 cut performed in July for each experimental year (2014-2016).

\subsection{Species Composition}

The floristic studies were described based on abundance-dominance after the BraunBlanquet method $[25,26]$, before mowing, when the Poaceae family plants were in the flowering stage. 
The experiment was placed on a Festuca rubra L.-Agrostis capillaris L. natural grassland type. Floristic studies were performed each year, before harvest. The crop was harvested once every year, in 2014, 2015 and in 2016 (in July). The dry mass of the biomass was determined by oven-drying at $60^{\circ} \mathrm{C}$ until constant mass was obtained.

\subsection{Forage Quality}

Forage analyses were performed by the Laboratory Applied biological sciences, located in the University for Agricultural Sciences and Veterinary Medicine, from Cluj-Napoca, Romania.

The protein content of forage was assessed following the Kjeldahl method, which has as a basis the digestion of the sample with sulfuric acid in the presence of catalysts. The crude fat was determined after Soxhlet method which has as a basis the extraction of total fat content by petroleum ether [27]. Ash content was determined using the burning the sample for $4 \mathrm{~h}$ at $600{ }^{\circ} \mathrm{C}$. The determination of crude fiber was made following the Weende method and is based on the solubilization of non-cellulosic compounds by sulfuric acid and potassium hydroxide solutions. NDF (Neutral Detergent Fiber) and ADF (Acid Detergent Fiber) were conducted following Van Soest [28].

\subsection{Statistical Analyses}

The statistical interpretation of the results for floristic data was conducted using the PC-ORD program Version 6, with Nonmetric Multidimensional Scaling (NMS) [29]. The data recorded for DM production and forage quality were analyzed with Statistica vs 10 (developed by StatSoft in the year 2010), $t$-test for single means and partial correlations. Effects were accepted as statistically significant if $p \leq 0.05$.

\section{Results}

\subsection{Species Composition}

The 2D graphical representation for the year 2014 allows us to explain $94.1 \%$ of the floristic changes. Axis 1 shows the greatest importance (82.3\%) compared to axis 2 which is less represented (11.8\%). The 2D graphical representation for the year 2015 allows us to explain $94.7 \%$ of the floristic changes. Axis 1 shows the greatest importance $(87.7 \%)$ compared to axis 2 which is less represented (7.1\%). In the year 2016 the 2D graphical representation allows us to explain $86.5 \%$ of the floristic changes. Axis 1 shows the greatest importance $(64.5 \%)$ compared to axis 2 which is less represented $(22 \%)$.

The floristic studies revealed that the type of grassland specific to the control plot in the year 2014 is Festuca rubra L. with Agrostis capillaris L. As shown in Figure 1 the type of grassland is not influenced by the treatments applied. The main species of the studied seminatural grassland, Festuca rubra L. and Agrostis capillaris L., suffered moderate increases in the percentage of participation in the vegetation cover as a result of fertilization, and the effects were noticed particularly on plots fertilized with 75 and $100 \mathrm{~kg} \mathrm{UAN} \mathrm{ha}^{-1} \mathrm{year}^{-1}$.

The phytocoenosis specific to the control plot is represented by Festuca rubra L.Agrostis capillaris L. grassland type which shows moderate changes in dominance/codominance as a result of the treatments applied in the year 2015 (Figure 2). Festuca rubra L. remains the dominant species in plots fertilized with $50 \mathrm{~kg} \mathrm{UAN} \mathrm{ha}^{-1}$ year $^{-1}$. Increasing the fertilizer rate above $50 \mathrm{~kg}^{\mathrm{UAN}} \mathrm{ha}^{-1}$ year $^{-1}$ seems to be favor Agrostis capillaris L. since all plots fertilized with 75-100 kg UAN ha ${ }^{-1}$ year $^{-1}$ have as dominant species the Agrostis capillaris L. 


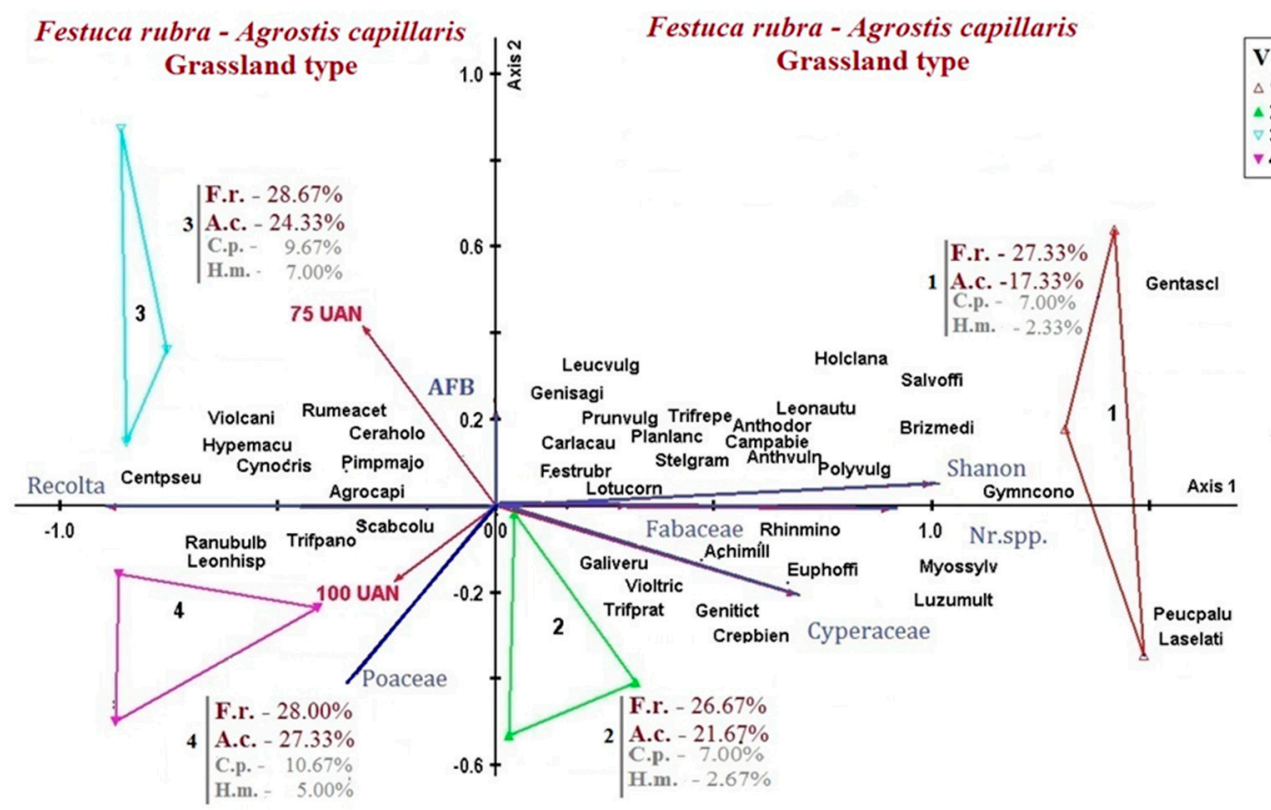

Figure 1. Changes in floristic composition as a result of the treatments applied in the year 2014. V1control plot, (unfertilized); V2—fertilized with $50 \mathrm{~kg} \mathrm{UAN} \mathrm{ha}^{-1}$ year $^{-1}$; V3—fertilized with $75 \mathrm{~kg}$ $\mathrm{UAN} \mathrm{ha}^{-1}$ year $^{-1}$; V4-fertilized with $100 \mathrm{~kg} \mathrm{UAN} \mathrm{ha}^{-1}$ year $^{-1}$; F.r.-Festuca rubra L.; A.c.-Agrostis capillaris L.; C.p.-Centaurea pseudophrygia C.A.Mey.; H.m.-Hypericum maculatum Crantz.

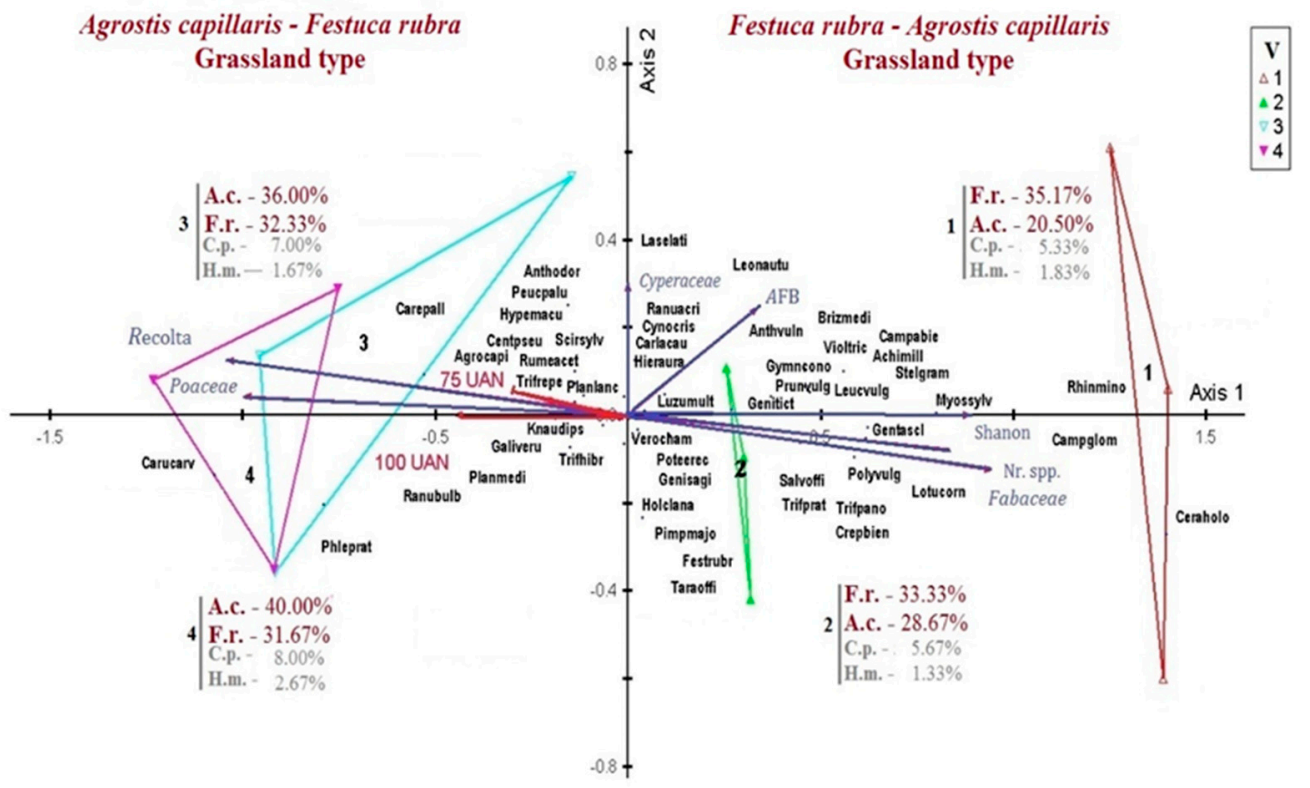

Figure 2. Changes in floristic composition as a result of the treatments applied in the year 2015.V1control plot, (unfertilized); V2 - fertilized with $50 \mathrm{~kg} \mathrm{UAN} \mathrm{ha}^{-1}$ year $^{-1}$; V3 - fertilized with $75 \mathrm{~kg}$ $\mathrm{UAN} \mathrm{ha}^{-1}$ year $^{-1}$; V4-fertilized with $100 \mathrm{~kg} \mathrm{UAN} \mathrm{ha}^{-1}$ year $^{-1}$; F.r.-Festuca rubra L.; A.c.-Agrostis capillaris L.; C.p.-Centaurea pseudophrygia C.A. Mey.; H.m.-Hypericum maculatum Crantz.

The results recorded in the third experimental year revealed that Agrostis capillaris L. is positively influenced by the treatments applied such that changes in floristic composition are registered (Figure 3). Thus Agrostis capillaris L. becomes the dominant species on all the experimental plots fertilized with UAN (increases its percentage of participation from $15.83 \%$ in control plot up to $22.25 \%$ in plot fertilized with $100 \mathrm{~kg} \mathrm{UAN} \mathrm{ha}^{-1}$ year $^{-1}$ ). 


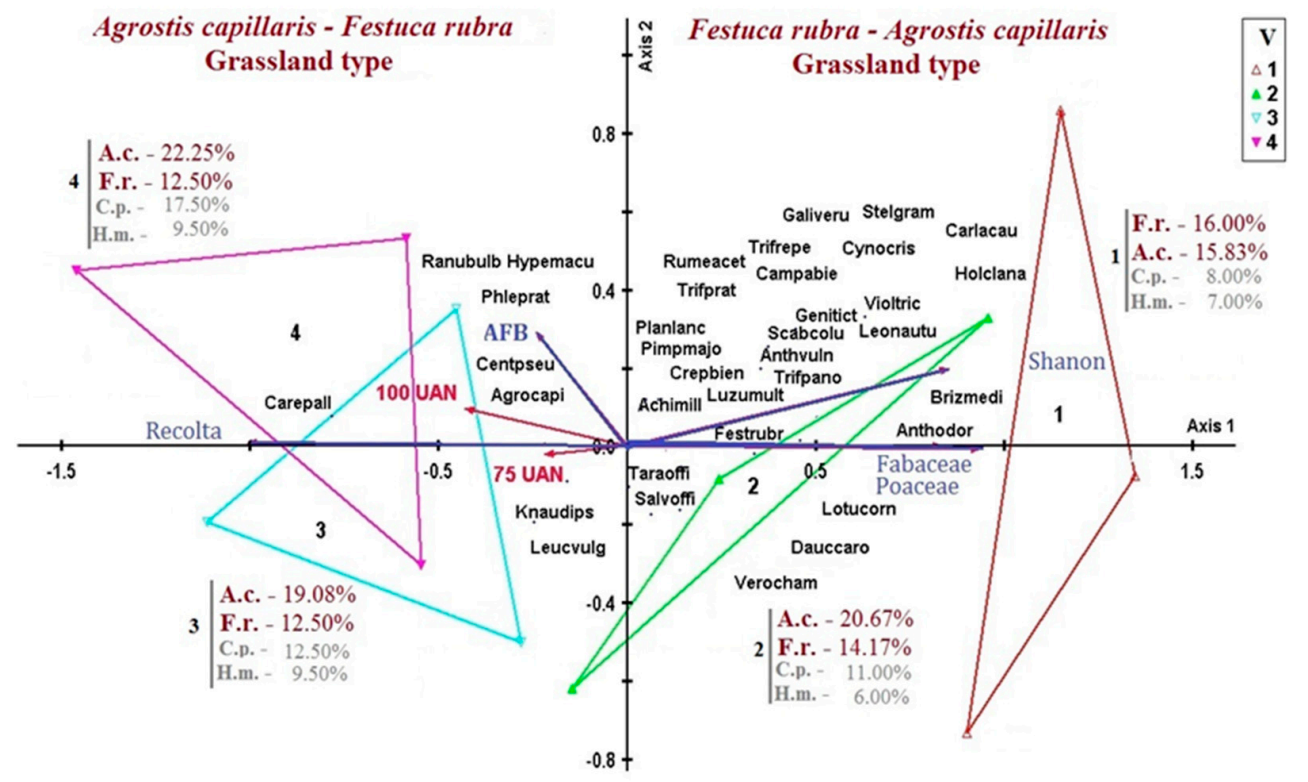

Figure 3. Changes in floristic composition as a result of the treatments applied in the year 2016. V1control plot, (unfertilized); V2—fertilized with $50 \mathrm{~kg} \mathrm{UAN} \mathrm{ha}^{-1}$ year $^{-1}$; V3 — fertilized with $75 \mathrm{~kg}$ $\mathrm{UAN} \mathrm{ha}^{-1}$ year $^{-1}$; V4-fertilized with $100 \mathrm{~kg} \mathrm{UAN} \mathrm{ha}^{-1}$ year $^{-1}$; F.r.-Festuca rubra L.; A.c.-Agrostis capillaris L.; C.p.-Centaurea pseudophrygia C.A.Mey.; H.m.-Hypericum maculatum Crantz.

\subsection{Dry matter Production}

The results registered in 2014 highlighted a strong reaction of dry matter production (DM) as a result of fertilization (Table 4). Thus DM yields increased proportionally with increasing the amount of fertilizer applied, from $2.99 \mathrm{t} \mathrm{DM} \mathrm{ha}^{-1} \mathrm{year}^{-1}$ (control plot) up to $6.39 \mathrm{t} \mathrm{DM} \mathrm{ha}^{-1}$ year $^{-1}$ (plot fertilized with $100 \mathrm{~kg} \mathrm{UAN} \mathrm{ha}^{-1}$ year $^{-1}$ ).

Table 4. Changes in dry matter yield (DM) as a result of UAN fertilization (2014-2016).

\begin{tabular}{ccc}
\hline & Experimental Year 2014 & \\
\hline $\begin{array}{c}\text { Experimental } \\
\text { Plot }\end{array}$ & Yield (t DM ha $\mathbf{~}^{-\mathbf{1}}$ year $^{-\mathbf{1})}$ & $p$-Value \\
\hline V1 & 2.99 & Ct. plot \\
V2 & 3.88 & $*$ \\
V3 & 5.64 & $* * *$ \\
V4 & 6.39 & \\
\hline & Experimental year 2015 \\
V1 & 2.33 & Ct. plot \\
V2 & 3.30 & $* * *$ \\
V3 & 4.26 & $* * *$ \\
V4 & 4.85 & \\
\hline & Experimental year 2016 \\
V1 & 3.22 & Ct. plot \\
V2 & 3.52 & $* * *$ \\
V3 & 4.70 & $* * *$ \\
V4 & 5.33 & \\
\hline
\end{tabular}

Note: Ct. plot = control plot; V1—control plot (unfertilized); V2-fertilized with $50 \mathrm{~kg} \mathrm{UAN} \mathrm{ha}^{-1}$ year $^{-1}$; V3fertilized with $75 \mathrm{~kg} \mathrm{UAN} \mathrm{ha}^{-1}$ year $^{-1}$; V4-fertilized with $100 \mathrm{~kg} \mathrm{UAN} \mathrm{ha}^{-1}$ year ${ }^{-1} ; *: p>0.05$-non-significant (NS). ${ }^{* * *}: p<0.001$-highly significant (HS, confidence $99.9 \%$ ). 
DM yields recorded in the second experimental year (Table 4) varied between $2.33 \mathrm{t} \mathrm{DM} \mathrm{ha}^{-1}$ year $^{-1}$ (control plot) and $4.85 \mathrm{t} \mathrm{DM} \mathrm{ha}^{-1}$ year $^{-1}$ (plot fertilized with $100 \mathrm{~kg} \mathrm{UAN} \mathrm{ha}^{-1}$ year $^{-1}$ ).

DM yields recorded in the year 2016 (Table 4) ranged between $3.22 \mathrm{t} \mathrm{DM} \mathrm{ha}^{-1}$ year $^{-1}$ (control plot) and $5.33 \mathrm{t} \mathrm{DM} \mathrm{ha}^{-1}$ year $^{-1}$ (plot fertilized with $100 \mathrm{~kg} \mathrm{UAN} \mathrm{ha}^{-1} \mathrm{year}^{-1}$ ). Our results show, generaly, the phytocoenosis analyzed responded very well to UAN fertilization in terms of DM production.

\subsection{Forage Quality}

The results concerning forage quality revealed small changes in forage quality indices in the first year of research as a result of UAN fertilization (Table 5). The crude protein, crude fat and ash content were negatively influenced by mineral fertilization such that these indices suffered decreases on plots fertilized with $50 \mathrm{~kg} \mathrm{UAN} \mathrm{ha}^{-1}$ year $^{-1}$ and $75 \mathrm{~kg}$ $\mathrm{UAN}_{\text {ha }}{ }^{-1}$ year $^{-1}$. Crude protein decreased from $8.01 \%$ in control plot up to $7.24 \%$ at plot fertilized with $75 \mathrm{~kg} \mathrm{UAN} \mathrm{ha}^{-1}$ year $^{-1}$. Following the same pattern, the crude fat suffered decreases from $4.11 \%$ in control plot up to $3.74 \%$ at plot fertilized with $75 \mathrm{~kg}$ UAN $\mathrm{ha}^{-1}$ year $^{-1}$. Fertilization with $100 \mathrm{~kg} \mathrm{UAN} \mathrm{ha}^{-1}$ year $^{-1}$ seemed favor these indices since the values recorded on the plots fertilized with $100 \mathrm{~kg} \mathrm{UAN} \mathrm{ha}^{-1}$ year $^{-1}$ are higher than those recorded on plots fertilized with 50 and $75 \mathrm{~kg} \mathrm{UAN} \mathrm{ha}^{-1}$ year $^{-1}$ but still lower than those registered on control plots, unfertilized. Crude fibre, NDF and ADF showed positive response to UAN fertilization. Thus, crude fibre increased from 33.39\% in control plot up to $34.11 \%$ in plot fertilized with $100 \mathrm{~kg} \mathrm{UAN} \mathrm{ha}^{-1}$ year $^{-1}$. NDF content ranged between $51.06 \%$ in control plot and $70.21 \%$ in plot fertilized with $100 \mathrm{~kg} \mathrm{UAN} \mathrm{ha}^{-1}$ year $^{-1}$ and ADF recorded increases from $42.11 \%$ in control plot up to $45.61 \%$ in plot fertilized with $100 \mathrm{~kg} \mathrm{UAN} \mathrm{ha}^{-1}$ year $^{-1}$.

The results recorded in the second year of the experiment revealed a similar reaction of the studied forage quality indices to that recorded in the year 2014 (Table 5). Therefore the crude protein, crude fat and ash content decreased proportionally with increasing mineral fertilization with values ranging between $6.03 \%\left(75 \mathrm{~kg} \mathrm{UAN} \mathrm{ha}^{-1}\right.$ year $\left.^{-1}\right)$ and $8.01 \%$ (control plot) for crude protein, 3.74\% (75 $\mathrm{kg} \mathrm{UAN} \mathrm{ha}^{-1} \mathrm{year}^{-1}$ ) and $4.11 \%$ (control plot) for crude fat and $5.36 \%\left(75 \mathrm{~kg} \mathrm{UAN} \mathrm{ha}^{-1}\right.$ year $\left.^{-1}\right)$ and $6.09 \%$ (control plot) in ash content. Crude fibre, NDF and ADF showed positive response to UAN fertilization. Thus, the crude fibre increased from $35.10 \%$ in control plot up to $38.52 \%$ in plot fertilized with $75 \mathrm{~kg}$ UAN ha ${ }^{-1}$ year $^{-1}$. The NDF content ranged between $50.86 \%$ in control plot and $68.62 \%$ in plot fertilized with $100 \mathrm{~kg} \mathrm{UAN} \mathrm{ha}^{-1}$ year $^{-1}$ and ADF recorded increases from $43.24 \%$ in control plot up to $46.35 \%$ in plot fertilized with $100 \mathrm{~kg} \mathrm{UAN} \mathrm{ha}^{-1}$ year $^{-1}$.

The results concerning forage quality recorded in the year 2016 revealed a different reaction of some of the quality indices studied to UAN fertilization compared to that registered in the first two experimental years (Table 5). Therefore crude protein followed the same reaction and its values decreased proportionally with increasing UAN fertilization reaching values between $6.11 \%$ (plot fertilized with $100 \mathrm{~kg} \mathrm{UAN} \mathrm{ha}^{-1}$ year $^{-1}$ ) and $8.54 \%$ (control plot). Crude fat reacted differently to UAN fertilizer compared to the first two years of experiment such that in the year 2016 crude fat recorded increases as a result of fertilization with 50 and $75 \mathrm{~kg} \mathrm{UAN} \mathrm{ha}^{-1}$ year $^{-1}$. Crude fibre, NDF, and ADF showed positive response to UAN fertilization. Crude fibre increased from $33.95 \%$ in control plot up to $36.34 \%$ in plot fertilized with $100 \mathrm{~kg} \mathrm{UAN} \mathrm{ha}^{-1}$ year $^{-1}$. NDF content ranged between $50.15 \%$ in control plot and $69.64 \%$ in plot fertilized with $100 \mathrm{~kg} \mathrm{UAN} \mathrm{ha}^{-1}$ year $^{-1}$ and ADF recorded increases from $41.05 \%$ in control plot up to $47.95 \%$ in plot fertilized with $100 \mathrm{~kg}$ UAN ha $^{-1}$ year $^{-1}$. 
Table 5. Changes in forage quality as a result of UAN fertilization (2014-2016).

\begin{tabular}{|c|c|c|c|c|c|c|c|}
\hline \multirow{2}{*}{$\begin{array}{c}\text { Forage Quality } \\
\text { Indices }\end{array}$} & \multirow{2}{*}{$\begin{array}{c}\text { Experimental } \\
\text { Plot }\end{array}$} & \multicolumn{2}{|c|}{2014} & \multicolumn{2}{|c|}{2015} & \multicolumn{2}{|c|}{2016} \\
\hline & & {$[\%]$} & $p$-Value & [\%] & $p$-Value & {$[\%]$} & $p$-Value \\
\hline \multirow{4}{*}{ Crude protein } & V1 & 8.01 & Ct. plot & 8.38 & Ct. plot & 8.54 & Ct. plot \\
\hline & $\mathrm{V} 2$ & 7.75 & $* * *$ & 7.62 & $* * *$ & 7.45 & $* * *$ \\
\hline & V3 & 7.24 & $* * *$ & 6.03 & $* * *$ & 6.19 & $* * *$ \\
\hline & V4 & 7.38 & $* * *$ & 7.53 & $* * *$ & 6.11 & $* * *$ \\
\hline \multirow{4}{*}{ Crude fat } & V1 & 4.11 & Ct. plot & 4.44 & Ct. plot & 3.28 & Ct. plot \\
\hline & V2 & 4.16 & $* * *$ & 4.48 & $* * *$ & 3.33 & $* * *$ \\
\hline & V3 & 3.74 & $* * *$ & 3.41 & $* * *$ & 3.30 & $* * *$ \\
\hline & V4 & 4.05 & $* * *$ & 4.35 & $* * *$ & 3.05 & $* * *$ \\
\hline \multirow{4}{*}{ Ash } & V1 & 6.09 & Ct. plot & 5.42 & Ct. plot & 5.46 & Ct. plot \\
\hline & V2 & 5.90 & $* * *$ & 5.23 & $* * *$ & 4.73 & $* * *$ \\
\hline & V3 & 5.36 & $* * *$ & 4.80 & $* * *$ & 4.46 & $* * *$ \\
\hline & V4 & 5.36 & $* * *$ & 5.06 & $* * *$ & 4.35 & $* * *$ \\
\hline \multirow{4}{*}{ Crude fiber } & V1 & 33.39 & Ct. plot & 35.10 & Ct. plot & 33.95 & Ct. plot \\
\hline & V2 & 32.70 & $* * *$ & 35.13 & $* * *$ & 35.47 & $* * *$ \\
\hline & V3 & 34.06 & $* * *$ & 38.52 & $* * *$ & 34.31 & $* * *$ \\
\hline & $\mathrm{V} 4$ & 34.11 & $* * *$ & 35.55 & $* * *$ & 36.34 & $* * *$ \\
\hline \multirow{4}{*}{ NDF } & V1 & 51.06 & Ct. plot & 50.86 & Ct. plot & 50.15 & Ct. plot \\
\hline & V2 & 56.75 & $* *$ & 55.92 & $* *$ & 54.22 & $* *$ \\
\hline & V3 & 57.44 & $* *$ & 65.38 & $* *$ & 54.19 & $* *$ \\
\hline & V4 & 70.21 & $* * *$ & 68.62 & $* * *$ & 69.64 & $* * *$ \\
\hline \multirow{4}{*}{$\mathrm{ADF}$} & V1 & 42.11 & Ct. plot & 43.24 & Ct. plot & 41.05 & Ct. plot \\
\hline & $\mathrm{V} 2$ & 43.45 & $* *$ & 44.32 & $* *$ & 42.18 & $* *$ \\
\hline & V3 & 45.72 & $* *$ & 44.89 & $* *$ & 45.08 & $* *$ \\
\hline & V4 & 45.61 & $* *$ & 46.35 & $* *$ & 47.95 & $* *$ \\
\hline
\end{tabular}

Note: V1-control plot (Ct. plot; unfertilized); V2-fertilized with $50 \mathrm{~kg} \mathrm{UAN} \mathrm{ha}^{-1}$ year $^{-1}$; V3-fertilized with $75 \mathrm{~kg} \mathrm{UAN} \mathrm{ha}^{-1}$ year $^{-1}$; V4-fertilized with $100 \mathrm{~kg} \mathrm{UAN} \mathrm{ha}^{-1}$ year $^{-1}$; $^{* *}: p<0.01$ - significant (S, confidence $99 \%$ ). ${ }^{* * *}: p<0.001$-highly significant (HS, confidence $99.9 \%)$.

\section{Discussion}

Natural and semi-natural grasslands have played an important role in people's livelihoods for millennia as areas producing fodder for animals [30]. At the same time, seminatural grasslands act as carbon sinks, erosion preventives, birds' directive areas, habitat for small animals, and nitrogen fixation source. Therefore studies aiming to investigate the optimum management required for higher forage yields and better forage quality while preserving species biodiversity are still required. Being a mixture of different grass species, legumes and herbs, most grasslands are in harmony and in balance with the environment, excepted intensively used ones [31]. The intensification of grassland management through the use of fertilizers, pesticides and the use of more efficient, mechanical mowing techniques, are among the most important threats for grassland ecosystems [20,21]. Our research pointed out that the application of UAN fertilizer caused changes in the ratio between the dominant and co-dominant species in the studied grassland (Figures 1-3). Changes occurred starting with the second year of fertilization [32,33]. Increasing the rates of UAN fertilizer over $50 \mathrm{~kg}^{\mathrm{U}} \mathrm{UN} \mathrm{ha}^{-1}$ year $^{-1}$ changed the dominant species such that Agrostis capillaris L. became dominant (Figures 2 and 3 ). As a result of mineral fertilization with UAN, the species from Fabaceae family decreased their percentage of participation in the vegetation cover, favoring the installation of Poaceae species. In the same time the plants from other botanical families increased their percentage of participation in the vegetation cover with increasing fertilizer rates. Briemle [23] also pointed out that mineral fertilizer has a negative influence on Fabaceae species and plants from other botanical families favoring the occurrence and development of Poaceae species. Our results highlighted that generally species diversity is reduced as a result of fertilizer treatments thus the highest diversity was being recorded in the control plot, unfertilized during the entire three-year period of 
the experimental trial (Figures 1-3). Most of the species found in the studied semi-natural grassland showed preferences for lower rates of fertilizer and among the most sensitive to fertilization where Festuca rubra L., Genista sagittalis, Peucedanum palustre, Laserpitium latifolium, Gymnadenia conopsea L. R. Br., Briza media L., Trifolium repens L. etc. At the same time, some species like Agrostis capillaris L., Centaurea pseudophrygia C.A.Mey., Hypericum maculatum Crantz, Leontodon hispidus etc., increased their percentage of participation in the vegetation cover as a result of UAN fertilization. The occurrence of these species was influenced also by the climatic condition specific to the three years experimental trial which favored their participation in the vegetation cover. When analysing the climatic conditions specific to the experimental period we observed that the temperature recorded in each of the 3 studied year are higher than the long-term average temperature (Table 1). Thus Agrostis capillaris L. reaction could be more or less related to these temperature increases since other researchers already pointed out a better resistance of this species to higher temperatures. Previous studies have documented that changes in temperature and precipitation have a strong influence on temporal patterns in the biomass of grassland [9]. At the same time, Agrostis capillaris L. reacts very well to acid soil conditions which are found in our experiment.

Important changes as a response to UAN fertilization were also recorded also when dry matter yield is considered (Table 4). Our results pointed out that dry matter yield increased proportionally with increasing fertilizer rates such that the highest yields were recorded in the plots fertilized with $100 \mathrm{~kg} \mathrm{UAN} \mathrm{ha}^{-1}$ year $^{-1}$ in all 3 years of the experimental trial. Our results are in accordance with other investigations conducted so far [34]. The highest dry matter yield (6.39 $\mathrm{t} \mathrm{DM} \mathrm{ha}^{-1}$ year $^{-1}$ ) was recorded in the year 2014 on the experimental plot fertilized with the maximum amount of UAN fertilizer (Table 4). Several studies emphasized that grassland yield and quality are necessary to assess in relation to changes in the botanical composition [35]. Our results also confirm that dry matter yields are influenced by the floristic composition such that the highest yields are recorded in plots where Poaceae species recorded higher percentage of participation (Table 4; Figures 1-3).

The investigation conducted by us highlighted important changes in forage quality as a result of UAN fertilization. Forage quality seemed to be negatively influenced by the application of UAN fertilizer in all 3 years of the experimental trial (Table 5). When analysing the results recorded we observed that UAN fertilization caused decreases in crude protein, crude fat and ash content while favoring the crude fibre, NDF and ADF content. NDF recorded values ranging between $50.15 \%$ and $70.21 \%$. [36,37] also reported values similar for NDF content. ADF varied between $41.05 \%$ and $47.95 \%$, results confirmed by other investigations [38-40]. These changes in forage quality could be explain also through species composition. Species from Fabaceae family reduced their percentage of participation favoring the appearance of plants from other botanical families [34,41] like Centaurea pseudophrygia C.A.Mey. and Hypericum maculatum Crantz (17.50\%), Centaurea pseudophrygia C.A.Mey. and Hypericum maculatum Crantz (9.5\%), which have a higher content in crude fibre and a lower crude protein and crude fat content.

\section{Conclusions}

The investigation conducted at the mountain semi-natural grassland from Baisoara commune, Apuseni Mountains, Romania pointed out important changes in forage quantity and quality as a result of UAN fertilization. A strong correlation between species composition and dry matter and forage quality was also noted. Based on our results we recommend moderate fertilization with UAN up to $50 \mathrm{~kg} \mathrm{UAN} \mathrm{ha}^{-1}$ year $^{-1}$ for semi-natural grasslands located in soil-climatic conditions similar to those in our experiment.

Author Contributions: Conceptualization, M.R., I.R., R.V. and O.R., methodology, M.R. and I.R.; software, M.R.; validation, M.R., I.R., R.V., and O.R.; formal analysis, M.R.; investigation, M.R., O.R., A.M., and N.L.; resources, M.R., O.R., A.M., and N.L.; data curation, M.R.; writing-original draft preparation, M.R.; writing-review and editing, O.R.; visualization, M.R., O.R., A.M., and 
N.L.; supervision, I.R., and R.V. All authors have read and agreed to the published version of the manuscript.

Funding: This research received no external funding.

Conflicts of Interest: The authors declare no conflict of interest.

\section{References}

1. Cirebea, M.; Rotar, I.; Vidican, R.; Pleșa, A.; Morea, A.; Ranta, O. Impact of organo-mineral fertilization upon phytocoenosis and feed quality of the grasslands in the region of Transylvania. Nardi Fundulea Rom. Rom. Agric. Res. 2020, 37, $179-188$.

2. Dudek, T.; Wolański, P.; Rogut, K. The Content of Macro- and Micro Minerals in the Sward of Different Types of Semi-Natural Meadows of Temperate Climate in SE Poland. Agronomy 2020, 10, 273. [CrossRef]

3. Zimkova, M.; Kirilov, A.; Rotar, I.; Stypinski, P. Production and quality of seminatural grassland in South-eastern and Central Europe. Grassl. Sci. Eur. 2007, 12, 15-26.

4. Kizeková, M.; Hopkins, A.; Kanianska, R.; Makovníková, J.; Pollák, Š.; Pálka, B. Changes in the area of permanent grassland and its implications for the provision of bioenergy: Slovakia as a case study. Grass Forage Sci. 2018, 73, 218-232. [CrossRef]

5. Gustavsson, E.; Dahlström, A.; Emanuelsson, M.; Wissman, J.; Lennartsson, T. Combining Historical and Ecological Knowledge to Optimise Biodiversity Conservation in Semi-Natural Grasslands. In The Importance of Biological Interactions in the Study of Biodiversity; InTech: Rijeka, Croatia, 2011; pp. 176-196.

6. Piessens, K.; Hermy, M. Does the heathland flora in north-western Belgium show an extinction debt? Biol. Conserv. 2006, 132, 382-394. [CrossRef]

7. Dahlström, A.; Iuga, A.-M.; Lennartsson, T. Managing biodiversity rich hay meadows in the EU: A comparison of Swedish and Romanian grasslands. Found. Environ. Conserv. 2013, 40, 194-205. [CrossRef]

8. Vîntu, V.; Samuil, C.; Rotar, I.; Moisuc, A.; Razec, I. Influence of the management on the phytocoenotic biodiversity of some Romanian representative grassland types. Not. Bot. Horti Agrobot. Cluj-Napoca 2011, 39, 119-125. [CrossRef]

9. Piao, S.; Nan, H.; Huntingford, C.; Ciais, P.; Friedlingstein, P.; Sitch, S.; Peng, S.; Ahlstrom, A.; Canadell, J.G.; Cong, N.; et al. Evidence for a weakening relationship between interannual temperature variability and northern vegetation activity. Nat. Commun. 2014, 5, 5018. [CrossRef]

10. Marușca, T.; Bărbos, M.; Blaj, V.; Cardașol, V.; Dragomir, N.; Mocanu, V.; Rotar, I.; Rusu, M.; Seceleanu, M. Tratat de Reconstrucție Ecologică a Habitatelor de Pajiști și Terenuri Degradate Montane (in Romanian); Printhouse Universității Transilvania din Brașov: Brașov, Romania, 2010; pp. 262-272.

11. Beaufoy, G. HNV Farming-Explaining the Concept and Interpreting EU and National Policy Commitments; European Forum on Nature Conservation and Pastoralism: UK, 2008; pp. 1-15. Available online: https://www.semanticscholar.org/paper/HNV-FARMING\%E2\%80\%93-EXPLAINING-THE-CONCEPT-AND-EU-AND-Beaufoy/6607a064fcfc04cd0c566fbd28aca7fb611520b7?p2df (accessed on 5 December 2020).

12. Bignal, E.; McCracken, D. Low intensity farming systems in the conservation of the countryside. J. Appl. Ecol. 1996, 33, 413-424. [CrossRef]

13. Wang, C.; Meng, F.; Li, X.-E.; Jiang, L.; Wang, S. Factors affecting plant primary productivity of grasslands: A review. Acta Ecol. Sin. 2014, 34, 4125-4132.

14. Štýbnarová, M.; Mičová, P.; Fiala, K.; Karabcová, H.; Látal, O.; Pozdíšek, J. Effect of organic fertilizers on botanical composition of grassland, herbage yield and quality. Agriculture (Pol'nohospodárstvo) 2014, 60, 87-97.

15. Mălinas, A.; Rotar, I.; Vidican, R.; Iuga, V.; Păcurar, F.; Mălinas, C.; Moldovan, C. Designing a Sustainable Temporary Grassland System by Monitoring Nitrogen Use Efficiency. Agronomy 2020, 10, 149. [CrossRef]

16. Cirebea, M. Cercetări Privind Productivitatea și Calitatea Pajiștilor Seminaturale din Muntele Băișorii. Ph.D. Thesis, University of Agricultural Sciences and Veterinary Medicine, Cluj-Napoca, Romania, 2017; pp. 57-58, 67-70, 75-76.

17. Barnhart, S.; Mallarino, A.; Sawyer, J. Fertilizing Pasture. Prepared for Iowa State University Extension and Outreach by ISU Professors of Agronomy 2013. PM 869 Fertilizing Pasture, 1-6. Available online: https://lib.dr.iastate.edu/extension_pubs/83/ (accessed on 7 December 2020).

18. Emanuelsson, U. Semi-natural grasslands in Europe today. Grassl. Sci. Eur. 2008, 13, 3-8.

19. Gustavsson, E. Grassland Plant Diversity in Relation to Historical and Current Land Use. Doctoral Thesis, Swedish University of Agricultural Sciences, Uppsala, Sweden, 2007; pp. 13-18. Available online: https:/ / www.researchgate.net/publication/30072990 (accessed on 29 January 2021).

20. Sutcliffe, L.; Larkham, K. Monitoring High Nature Value Grassland in Transylvania, Romania. In Mountain Hay Meadows: Hotspots of Biodiversity and Traditional Culture; Barbara Knowles, Society of Biology: London, UK, 2011.

21. European Commission. LIFE and Europe's Grasslands: Restoring a Forgotten Habitat; European Commission: Luxembourg, 2008; pp. 4-6. ISBN 978-92-79-10159-5.

22. Naie, M.; Trotus, E.; Lupu, C.; Buburuz, A.; Popa, L.D. Influence of fertilization on the vegetation cover structure in temporary meadows under the center of Moldavia pedo-climatic conditions. An. Inst. National Cercet. Dezvoltare Agric. Fundulea 2017, 85, 163-179. 
23. Briemle, G.; Oppermann, R. Von der Idee zum Programm: Die Forderung artenreichen Grunlandes in MEKA II. In Artenreiches Grunland; Verlag Eugen Ulmer: Stuttgart, Germany, 2003; pp. 26-32.

24. Aune, S.; Hovstad, K. Successional change after grassland abandonment. Grassl. Sci. Eur. Wagening. 2016, 21, 560-566.

25. Păcurar, F.; Rotar, I. Metode de Studiu și Interpretare a Vegetației Pajistilor (in Romanian); Risoprint: Cluj-Napoca, Romania, 2014; pp. 130-138. ISBN 978-973-53-1452-1.

26. Cristea, V.; Denayer, S. De la Biodiversitate la OMG-uri? Eikon: Cluj-Napoca, Romania, 2004; ISBN 973-7987-77-2. (in Romanian)

27. Luque de Castro, M.D.; Priego-CapoteJ, F. Soxhlet extraction: Past and present panacea. J. Chromatogr. A 2010, 1217, 2383-2389. [CrossRef] [PubMed]

28. Dale, L. Determinarea Calităţii Furajelor Prin Metode Destructive şi Non-Destructive (in Romanian). Ph.D. Thesis, University of Agricultural Sciences and Veterinary Medicine, Cluj-Napoca, Romania, 2011; pp. 15-23.

29. McCune, B.; Mefford, J. PC-ORD. Multivariate Analysis of Ecological Data, version 6; MjM Software: Gleneden Beach, OR, USA, 2011.

30. Emanuelsson, U. The Rural Landscape of Europe. How Man Has Shaped European Nature; The Swedish Research Council Formas: Stockholm, Sweden, 2009; pp. 383-596. ISBN 978-91-540-5977-5.

31. Carlier, L.; Rotar, I.; Vlahova, M.; Vidican, R. Importance and Functions of Grasslands. Not. Bot. Horti Agrobot. 2009, 37, 25-30. [CrossRef]

32. Rotar, I.; Cirebea, M.; Vidican, R.; Păcurar, F.; Malinaș, A.; Ranta, O. Mineral Fertilization with UAN on natural grassland Festuca rubra L. with Agrostis capillaris L. Bull. Univ. Agric. Sci. Vet. Med. Cluj-Napoca Agric. 2016, 73, 300-305.

33. Cirebea, M.; Rotar, I.; Vidican, R.; Pleșa, A.; Ranta, O. Qualitative modifications produced in feed of Festuca rubra L. and Agrostis capillaris L. under influence of UAN liquid fertilizer. Sci. Pap. Ser. A Agron. 2018, LXI, 184-187.

34. Bogdan, A. Cercetări Privind Folosirea şi Menţinerea Pajiştilor Montane cu Low-Input (in Romanian). Ph.D. Thesis, University of Agricultural Sciences and Veterinary Medicine, Cluj-Napoca, Romania, 2012.

35. Müller, M.; Hrabě, F.; Chroust, J. Změnyv kvalitě píce pastevního porostu v průběhu pastevního období/ Changes in forage quality of pasture sward in course of grazing period]. In Pozdíšek, J. Kvalita Píce z Travních Porostů; Kohoutek, A., Ed.; VÚRV Praha-Ruzyně: Prague, Czech Republic, 2005; pp. 106-111. ISBN 8086555-75-5.

36. Gomes, D.I.; Detmanna, E.; Valadares, F.S.D.; Fukushimab, R.S.; De Souzaa, A.; Valentea, N. Evaluation of lignin contents in tropical forages using different analytical methods and their correlations with degradation of insoluble fiber. Anim. Feed Sci. Technol. 2011, 168, 206-222. [CrossRef]

37. Gliga, A. Influența Erbivorelor de Interes Cinegetic Asupra Pajiștilor din Munții Rodnei (in Romanian). Ph.D. Thesis, University of Agricultural Sciences and Veterinary Medicine, Cluj-Napoca, Romania, 2015; pp. 132-133.

38. Iantcheva, N.; Steingass, H.; Todorov, N.; Pavlov, D. A comparison of in vitro rumen fluid and enzymatic methods to predict digestibility and energy value of grass and alfalfa hay. Anim. Feed Sci. Technol. 1999, 81, 333-344. [CrossRef]

39. Mahipala, M.; Krebsb, G.; Mccafferty, P.; Dodsc, K.; Suriyagodae, B. Faecal indices predict organic matter digestibility, short chain fatty acid production and metabolizable energy content of browse-containing sheep diets. Anim. Feed Sci. Technol. 2009, 154, 68-75. [CrossRef]

40. Undersander, D. Using Digestible NDF to Determine Forage Quality. In Proceedings of the Manitoba Forage Marketers Conference, Winnipeg, MB, Canada, 9 April 2003; pp. 1-6.

41. Păcurar, F. Cercetări Privind Dezvoltarea Sustenabilă (Durabilă) a Satului Gheţari, com. Gârda Prin Îmbunătăţirea Pajiştilor Naturale şi a Unor Culturi Agricole (in Romanian). Ph.D. Thesis, University of Agricultural Sciences and Veterinary Medicine, Cluj-Napoca, Romania, 2005; pp. 105-106. 